\title{
Objective methods for non-invasive back classification
}

\author{
Helmut Diers", S Mooshake, K Heitmann \\ From 7th International Conference on Conservative Management of Spinal Deformities \\ Montreal, Canada. 20-22 May 2010
}

\section{Introduction}

Using the non-invasive back classification of the formetric system, parameters are defined as a tool for measuring symmetry and rotation of shoulders, thorax and waist as well as scoliosis and kyphosis/lordosis angles.

\section{Background}

A 3D reconstruction and -analysis of the back surface of patients deliver a set of objective parameters that can be used in various diagnostic and/or classification procedures.

\section{Materials and methods}

The formetric measurement system reconstructs human back surfaces in semi-real time. From the acquiesced 3D data a set of objective parameters can be calculated in an automatic way: We present some of the newest parameters for detection and classification of scoliosis and other severe back deformities: Symmetry and torsion of pelvis, waist, scapula and shoulders in relation to each other; opening angles, position and size of waist triangles; scoliotic, kyphotic and lordotic angles. Those parameters form a basis from where classification indexes can be calculated and derived according to a specific set of defined rules.

\section{Results and discussion}

Studies evaluating the above parameters are running. Correlations and robustness are to be determined; prestudies show good correlation with visual classification and a good robustness. Especially in severe back deformities it is possible to transfer the parameters of the automatic classifications to useful clinical classifications.

Diers International GmbH, Schlangenbad, Germany

Full list of author information is available at the end of the article

\section{Conclusions}

The classification parameters of the formetric system deliver clinical relevant data for screening, diagnostics and follow-up.

Published: 10 September 2010

doi:10.1186/1748-7161-5-S1-08

Cite this article as: Diers et al:: Objective methods for non-invasive back classification. Scoliosis 2010 5(Suppl 1):O8.
Submit your next manuscript to BioMed Central and take full advantage of:

- Convenient online submission

- Thorough peer review

- No space constraints or color figure charges

- Immediate publication on acceptance

- Inclusion in PubMed, CAS, Scopus and Google Scholar

- Research which is freely available for redistribution

Submit your manuscript at www.biomedcentral.com/submit
( ) Biomed Central 